\title{
TINGKAT KEPUASAN PELANGGAN TERHADAP LAYANAN PENDIDIKAN DI SD INTEGRAL LUKMAN AL-HAKIM JEMBER
}

\author{
Bahar Agus Setiawan \\ Dosen Program Studi Pendidikan Agama Islam Fakultas Agama Islam \\ Universitas Muhammadiyah Jember \\ Email : baharsetiawan@unmuhjember.ac.id
}

\begin{abstract}
ABSTRAK
The level of customer satisfaction in the world of education has long been a necessity. The difference between private and public schools is no longer significant. Competition and competitive nature of private and public schools require new changes and conceptions where management of educational institutions is concerned. The implementation of a full-dayschool system in Indonesia cannot be separated from the phenomena related to 'superior schools' back in the 1990s-many of which were pioneered by private schools, especially those that were motivated by implementing Islamic values. Such schools are usually referred to as schools that focus primarily on the quality of the teaching and learning processes rather than on the quality of students input. Today, full day school has become a trending topic or, in the language of information technology, viral in conjunction with the mandate from the Minister of Education and Culture no 23/2017 relating to School Days. Full day schools are increasingly popular and recognized by the wider community. This study employed a survey method involving a quantitative approach. Respondents were 69 students and 90 parents. The instrument used for data collection was a questionnaire consisting of 43 questions for students and 51 questions for parents. The findings of this study revealed that the level of student satisfaction for basic educational services provided by Integral Lukman AlHakim primary school Jember reached $99.9 \%$ with $52.17 \%$ were very satisfied and $47.82 \%$ were quite satisfied. Meanwhile, the level of satisfaction of parents reached $84.45 \%$. with $16.67 \%$ were very satisfied and $67.78 \%$ were quite satisfied. The remaining $15.55 \%$, however, were not satisfied. Finally, it is concluded that the level of customer satisfaction with regard to the educational services provided by Integral Lukman Al-Hakim primary school is high.
\end{abstract}

Kata Kunci : Fullday School, Kepuasan, Layanan Pendidikan.

\section{PENDAHULUAN}

Persaingan lembaga pendidikan di era 4.0 telah mengalami pergesaran yang signifikan. Lembaga pendidikan sudah digolongkan sebagai industri jasa yang menuntut pengelolaan profesional. Pengelolaannya lembaga pendidikan tidak boleh lagi merujuk pada pola tradisonal tetapi harus mengacu pada sistem manajemen modern. Sehingga ouput yang 
dihasilkan mampu bersaing bukan hanya ditingkat nasional tetapi sudah mencangkup internasional. Menjadi sebuah keniscayaan, pengelolaan pendidikan yang merujuk pada tataran profesional bukan tradisonal menjadi aspek yang sangat urgen, dimana kemampuan pengelola lembaga pendidikan atau administrator, dapat melakukan scaning pada seluruh area lingkungan eksternal, kompetitor, memperhitungkan kompetensi internal, sehingga dapat menciptakan strategi yang mencukupi untuk memenangkan persaingan tanpa meninggalkan esensi dari pendidikan itu sendiri. Pemetaan terhadap tingkat kepuasan pelanggan pendidikan, meskipun memberikan tantangan tersendiri bagi pendidik dan pengelola lembaga pendidikan, menjadi salah satu solusi untuk mengetahui kualitas pendidikan yang diberikan .

Perubahan paradigma pendidikan ditambah lagi dengan munculnya konsep Manajemen Berbasis Sekolah (MBS) di Indonesia, geliat perubahan pengelolaan lembaga pendidikan menunjukkan progres yang salah satunya dengan kemunculan full day school. Munculnya sistem pendidikan full day school di Indonesia diawali dengan menjamurnya istilah sekolah unggulan sekitar tahun 1990-an, yang banyak dipelopori oleh sekolahsekolah swasta khususnya yang berbasis Islam. Dalam pengertian yang ideal, sekolah unggul adalah sekolah yang fokus pada kualitas proses pembelajaran, bukan pada kualitas input siswanya. Pada dasarnya yang dimaksud dengan full day school adalah model pendidikan terpadu.

Ditinjau dari sudut pandang historis-sosiologis, lahirnya pendidikan terpadu tidak lepas dari perubahan paradigma pengembangan pendidikan Islam sejak abad pertengahan, yang didasari oleh adanya dikotomi antara pendidikan agama yang menekankan pada pengajaran ilmu-ilmu agama dengan pendidikan umum yang menekankan pada pengajaran ilmu-ilmu non agama (pengetahuan) (Muhaimin, dkk, 2001 : 3839). Pengintegrasian nilai-nilai ilmu pengetahuan, nilai-nilai agama dan etik, merupakan realitas perwujudan implementasi paradigma yang bermigrasi dalam wujud pendidikan terpadu, yang bertujuan mampu melahirkan manusia yang menguasai ilmu pengetahuan dan tekhnologi, memiliki kematangan professional sekaligus hidup dalam nilainilai islami (Muhaimin dkk, 2001 : 4546). Konsep pendidikan terpadu ini telah menjadi topik pembicaraan di kalangan cendekiawan Islam sejak beberapa dasawarsa terakhir. Konsep pendidikan Islam merupakan kristalisasi dari rekomendasi Konferensi Dunia tentang pendidikan Islam pertama yang diselenggarakan di Mekkah. Ide tersebut terus bergulir ke berbagai negara, bahkan di negara-negara non muslim (Rossidy, 2009 : 74). Di Indonesia, ide tersebut agak terlambat sampainya, karena situasi yang tidak kondusif dan baru memperoleh momentumnya pada era reformasi dengan banyaknya bermunculan sekolah Islam terpadu, mulai dari tingkat dasar sampai menengah atas. Dengan adanya sekolahsekolah Islam terpadu, maka muncullah jaringan sekolah Islam terpadu (JSIT) di seluruh Indonesia (Arifin, 2012 : 30-31).

Pada saat ini popularitas pendidikan terpadu atau yang lebih populer dengan istilah full day school menjadi trending topic atau dalam bahasa teknologi informasi menajdi viral seiring dengan Kemendiknas Nomor 23 tahun 2017 tentang Hari Sekolah, full day school semakin populer dan kian dikenal oleh masyarakat luas. Perdebatan antara yang menolak dan menerima terhadap keputusan tersebut menjadi sarana tersendiri bagi sosialisasi dan perkenalan konsep Full Day School yang sudah ada sebelumnya. Dasar kemunculan Kemendiknas nomor 23 tahun 2017 
seperti diungkapkan oleh Menteri Pendidikan dan Kebudayaan Muhajir Effendi merupakan program Pendidikan Penguatan Karakter (PPK). Disandarkan pada tujuan pendidikan utama adalah pembentukan karakter peserta didik, maka konsepsi pengelolaan lembaga pendidikan harus mampu menampung dan mewadahi terlaksananya pendidikan karakter secara komprehensif. Karakter sebagai suatu 'moral excellene' atau akhlak dibangun di atas berbagai kebajikan, pada dasarnya sudah menjadi perhatian pemerintah yang tertuang dalam UU Sisdiknas nomor 20 tahun 2003 tentang Sistem Pendidikan Nasional pada pasal 1 yang menjelaskan tentang tujuan pendidikan di Indoensia. Pendeknya, kebijakan tentang full day scholl yang digagas oleh Menteri Pendidikan dan Kebudayaan Muhajir Effendi yang tertuang dalam kemendiknas nomor 23 tahun 2017 merupakan tingkat implementasi UU sisdiknas nomor 20 tahun 2003.

Di kabupaten Jember sendiri, sekolah dengan sistem full day school atau five day school sudah banyak diterapkan dan menunjukkan tingkat kompetitif yang sangat baik. Al-Furqon, Al-Irsyad, AdDhuha yang kesemuannya dibawah lembaga yayasan Islam. Sekolah-sekolah tersebut mampu membentuk segmentasi pelanggan pendidikan yang signifikan sehingga daya saing lembaga tersebut dalam hal rekruitmen peserta didik baru sangat kompetitif dengan sekolah negeri. Wajah baru penyediaan layanan jasa pendidikan menjadi daya tarik sendiri bagi orang tua siswa untuk dapat memasukkan anaknya di sekolah-sekolah tersebut.

Penerapan full day school merupakan alternatif dari revolusi pendidikan terhadap masalalah yang ada dan terjadi pada siswa. konsep dasar dari full day school adalah integrated curriculum dan integrated activity dalam upaya meningkatkan religiusitas peserta didik. Sehingga dalam penerapan kurikulum yang digunakan terdapat perpaduan antara pelajaran umum yang ditetapkan pemerintah dan pelajaran tambahan yang bertujuan untuk mewujudkan apa yang diharapkan (Fadjar, 1998 : 11). Corak kurikulum dan corak aktifitas proses pembelajaran itulah yang kemudian menjadi daya tarik tersendiri bagi pelanggan pendidikan. Arus globalisasi dan perubahan yang terjadi dalam dunia pendidikan, menjadi sebuah keniscayaan bagi pendidikan di Indonesia harus mampu beradaptasi. Perkembangan konsepsi pendidikan saat ini sudah mengalami perubahan yang sangat signifikan khususnya dalam pengelolaan lembaga pendidikan. Saat ini lembaga pendidikan sudah dipandang sebagai industri yang dapat mencetak jasa yaitu jasa pendidikan. Hal ini tidak lepas dari fungsi pendidikan yaitu sebagai proses untuk mengembangkan bakat, kemampuan dan kemungkinan yang dimiliki bisa secara maksimal, sehingga dapat menjadi insan yang mandiri dalam proses membangun pribadinya. Dalam konteks inilah dalam dunia pendidikan dikenal dengan istilah pelanggan pendidikan primer, sekunder dan tersier.

Dinamika pola pendidikan yang begitu cepat dan silih berganti menjadikan persaingan antar sekolah semakin ketat, khusunya dalam menarik konsumen dan meningkatkan loyalitas pelanggan dalam bentuk pelayanan jasa. Menurut Alma (2003:49) bahwa lembaga pendidikan yang menganut konsep marketing, tahu persis apa yang harus dilakukan. Lembaga pendidikan, layananannya bukan hanya sekedar mengajar siswa setiap hari sesuai jadwal kemudian melaksanakan ujian, lulus, habis perkara. Tetapi lebih jauh dari itu, siswa sebagai pelanggan primer, harus merasa puas dengan layanan lembaga pendidikan mengenai banyak hal misalnya suasana belajar mengajar, ruang kelas yang bersih, taman yang asri, pendidik yang ramah, perpustakaan, laboratorium, 
lapangan olahraga, dan sebagainya harus siap melayani peserta didik.

Full day school merupakan bentuk perubahan paradigma pengelolaan lembaga pendidikan dari yang bersifat konvesional kepada konsep modern, menjadikan tingkat daya saing antar lembaga pendidikan semakin baik. Perbedaan sekolah negeri swasta saat ini sudah tidak lagi terlihat signifikan. Daya saing dan sifat kompetitif antar sekolah negeri swasta, menuntut perubahan dan konsepsi baru dalam pengelolaan lembaga pendidikan khususnya pada tingkat layanan pendidikan. Dalam mempertahankan kelangsungan hidup usahanya, setiap perusahaan baik perusahaan yang bergerak dalam bidang jasa, seperti halnya jasa pendidikan senantiasa harus berusaha untuk memiliki competitive adventage (keunggulan dalam bidang tertentu untuk memenangkan persaingan) dimana dalam hal ini dapat berupa keunggulan dalam pemberian layanan (service) kepada pelanggan baik pelanggan primer, sekunder dan tersier. Maknanya pelanggan dalam seluruh esensinya merupakan pihak yang harus dipenuhi dan direalisasikan oleh pihak produsen baik yang bergerak dalam bidang manufaktur (produksi) maupun jasa tidak terkecuali lembaga pendidikan sebagai pihak yang memberikan layanan jasa pendidikan untuk memberikan apa yang dinamakan dengan kepuasan pelanggan. Kepuasan pelanggan merupakan suatu tingkatan dimana kebutuhan, keinginan dan harapan dari pelenggan dapat terpenihi yang akan mengakibatkan terjadinya pembelian ulang atau kesetiaan yang berlanjut (Band, 1991 : 23). Faktor yang paling penting untuk menciptakan kepuasan konsumen adalah kinerja dari agen yang biasanya diartikan dengan kualitas dari agen tersebut (Mowen, 1995 : 16). Sedangkan menurut Kotler (2000 : 250) Kepuasan pelanggan tergantung pada kinerja produk yang berhubungan dengan harapan pembeli. Jika kinerja produk sesuai dengan harapan, pelanggan akan merasa puas, dan sebaliknya. Harapan pelanggan didasarkan pada pengalaman pelanggan atas pembelian yang berupa produk atau jasa. Seperti halnya yang telah disinggung diatas, kepuasan pelanggan terwujudkan ketika harapan dan kebutuhan pelanggan dapat dipenuhi oleh pelaku layanan jasa dan tentu saja jasa yang diperoleh atau diterima oleh pelanggan merupakan jasa yang berkualitas.

Menjadi sebuah realita yang tidak dapat dipungkiri, keberlangsungan lembaga pendidikan/sekolah tidak akan lepas dari coast, customer dan delevery yang ketiga saling berhungan erat. Biaya, pelanggan dan layanan pendidikan merupakan unsur yang tidak dapat dipisahkan dalam pengelolaan lembaga pendidikan. Layanan yang paripurna dapat menciptakan kesetiaan (Band, 1991 : 23). Ketika lembaga pendidikan/sekolah tidak mampu menafsirkan tiga unsur tersebut maka tingkat daya saingnya akan rendah. Blue Ocean Strategy sebagai salah satu konsep dalam education management strategic, memberikan opsi (pilihan) bagi lembaga pendidikan/sekolah dalam meningkatkan daya saingnya. Dalam konsep Blue Ocean Strategy dijelaskan : "Competing in overcrowded industries is no way to sustain high performance The real opportunity is to create blue oceans of uncontested market space" (Insead, 2015:10), sehingga perlu dilakukan pendekatan baru dalam menyikapi ketatnya kompetisi dalam situasi global dan nasional dalam bidang pengelolaan lembaga pendidikan/sekolah.

Pada dasarnya pentingnya kepuasan pelanggan dalam kualitas layanan jasa pendidikan bermanfaat untuk agar lembaga/organisasi pendidikan tersebut tetap eksis. Menurut Octavian (2005 : 3), sekolah dalam menjalankan kegiatan pendidikan sangat tergantung 
kepada tiga jenis sumber pemasukan keuangan, yaitu: (1) pemilik organisasi, (2) masyarakat pengguna dan (3) pihak ketiga. Dari deskripsi tersebut sangat jelas, masyarakat pengguna yang dapat ditafsirkan atau dimaknai sebagai pelanggan merupakan pihak yang memiliki kontribusi yang sangat signifikan dalam keberlangsungan suatu lembaga/organisasi pendidikan yang dinamakan dengan sekolah. Terkait dengan pelanggan, seperti yang telah disinggung diatas, pelanggan dalam lingkup proses pendidikan di sekolah mencakup 3 yaitu : pertama, pelanggan primer yaitu siswa sebagai pihak yang langsung terkait dengan proses pendidikan tersebut; kedua, pelanggan sekunder yang dapat dikaitkan dengan orang tua, masyarakat dan lainnya; sedangkan pelanggan tersier adalah dunia usaha atau kerja. Seperti yang tertera dalam judul, penelitian ini bermaksud untuk melihat tingkat kepuasan pelanggan pendidikan khususnya pelanggan tersier yaitu orang tua siswa. Meskipun SD Integral Lukman Al-Hakim, menurut informan bukan merupakan sekolah dengan konsep full day school, namun beberapa indikator yang terimplementasi pada sekolah sesuai dengan indikator full day school antara lain indikator tersebut seperti 5 hari sekolah efektif, jam belajar mulai $07.00 \mathrm{sd}$ 13.30, kurikulum terintegrasi antara kurikulum departeman pendidikan dengan kurikulum muatan lokal dan indikator lainnya. Adapun rumusan maslah dalam penelitian ini adalah bagaimakah tingkat kepuasan pelanggan terhadap layanan pendidikan di SD integral Lukman AlHakim Jember?.

\section{METODE PENELITIAN}

Metode yang digunakan dalam penelitian ini adalah survey dengan pendekatan deskriptif kuantitatif. Hal ini sesuai dengan tujuan penelitian survey adalah untuk memberikan gambaran secara mendetail tentang latar belakang, sifat-sifat, serta karakter-karakter yang khas dari kasus atau kejadian suatu hal yang bersifat umum. Dalam penyusunan penelitian ini dibutuhkan data dan informasi yang sesuai dengan sifat permasalahannya agar data dan informasi yang diperoleh cukup lengkap digunakan sebagai dasar dalam membahas masalah yang ada metode yang digunakan dalam penelitian ini adalah analisis deskritif. Responden dalam penelitian ini terdiri atas dua macam yaitu peserta didik dengan jumlah 69 dari kelas 4 sampai dengan kelas 5. Sedangkan reponden yang kedua adalah orang tua peserat didik kelas 4 asampai dengan kelas 5 yang berjumlah 90 orang. Instrumen yang digunakan adalah angket/kuesioner dengan jumlah iem pertanyaan untuk peserta didik 43 butir sedangkan untuk orang tua peserta didik 53 butir. Untuk uji validitas instrumen digunakan SPPS. Lokasi penelitian di SD Integral Lukman AlHakim Jember.

\section{HASIL PENELITIAN DAN PEMBAHASAN}

\section{Tingkat Kepuasan Pelanggan Terhadap Layanan Pendidikan di SD Integral Lukman AL-Hakim.}

Tingkat Kepuasan pelanggan terhadap layanan pendidikan di SD Integral Lukam Al-Hakim diukur berdasarkan 5 aspek yang meliputi tangibles/ berwujud, realibility/ kehandalan, responsiveness/ kesigapan, assurancel kepastian dan emphaty/ empati. Pada deskripsi hasil penelitian ini akan dibagi pada dua kelompok yaitu peserta didik dan orang tua.

\section{a. Peserta didik}

Tingkat kepuasan tersebut diukur dengan angket yang berjumlah 34 butir pernyataan dengan rentang skor $1-5$, sehingga diperoleh rentang skor ideal 
antara 34 - 170. Setelah data ditabulasi, diskor, dan dianalisis dengan bantuan softwere hasil analisis data diperoleh nilai minimum $=107$; nilai maksimum $=163$; rata-rata $($ mean $)=135,53 ;$ median $=134$; modus sebesar $=118$; standard deviasi $=$ 15,040. Deskripsikan hasil penelitian tersebut dapat dikategorikan sebagai berikut :

Tabel 1

Deskripsi Hasil Penelitian Tingkat Kepuasan Peserta Didik

\begin{tabular}{ccccc}
\hline No & Interval & Kategori & Hasil & Prosentase \\
\hline 1 & $134<170$ & Sangat Puas & 36 & 52,17 \\
\hline 2 & $105<133$ & Puas & 33 & 47,82 \\
\hline 3 & $82<104$ & Kurang Puas & 0 & 0 \\
\hline 4 & $53<81$ & Tidak Puas & 0 & 0 \\
\hline 5 & $34<52$ & Sangat Tidak Puas & 0 & 0 \\
\hline & Jumlah & 69 & 100 \\
\hline
\end{tabular}

Adapun untuk deskripsi masingmasing aspek yang diukur, seperti berikut ini :

1) Aspek tangibles

Asepk tangibles diukur dengan 8 item butir pertanyaan dengan skala linkert, sehingga diperoleh rentang skor ideal 8 40. Berdasarkan olah data dihasilkan nilai minimum $=19$ dan nilai maxsimum $=37$ dengan nilai mean $=$ 29.420, nilai median 29 dan nilai mode/modus sebesar 27 dengan standar deviasi sebesar 4.28. Berdasarkan hal tersebut dapat ditabulasi prosentase kepuasan pada aspek tangibles sebagai berikut :

Tabel 2

Tingkat Kepuasan Peserta Didik pada Aspek Tangibles

\begin{tabular}{cccc}
\hline Interval & Kategori & Hasil & Prosentase \\
\hline $34<40$ & Sangat Puas & 11 & 15,94 \\
\hline $27<33$ & Puas & 43 & 62,32 \\
\hline $20<26$ & Kurang Puas & 14 & 20,29 \\
\hline $14<19$ & Tidak Puas & 1 & 1,449 \\
\hline $8<13$ & Sanag Tidak Puas & 0 & 0 \\
\hline & Jumlah & 69 & 100 \\
\hline
\end{tabular}

Dari data diatas dapat dideskripsikan bahwa pada aspek tangibles untuk kategori sangat puas sebesar $15,94 \%$, puas sebesar $62,32 \%$, kurang puas sebesar $20,29 \%$ dan tidak puas sebesar $1,44 \%$. Sedangkan untuk kategori sangat tidak puas tidak memiliki prosentase.

2) Aspek realibility
Pada aspek realibility, dengan 8 pertanyaan maka skor ideal adalah $8-40$. Berdasarkan olah data dihasilkan nilai minimum $=16$ dan nilai maxsimum $=40$ dengan nilai mean $=33.260$, nilai median 33 dan nilai mode/modus sebesar 33 dengan standar deviasi sebesar 4.21. Berdasarkan hal tersebut dapat ditabulasi 
prosentase kepuasan pada aspek realibility sebagai berikut :

Tabel 3

Tingkat Kepuasan Peserta Didik pada Aspek Realibility

\begin{tabular}{cccc}
\hline Interval & Kategori & Hasil & Prosentase \\
\hline $34<40$ & Sangat Puas & 32 & 46,38 \\
\hline $27<33$ & Puas & 33 & 47,83 \\
\hline $20<26$ & Kurang Puas & 3 & 4,348 \\
\hline $14<19$ & Tidak Puas & 1 & 1,449 \\
\hline $8<13$ & Sanag Tidak Puas & 0 & 0 \\
\hline & Jumlah & 69 & 100
\end{tabular}

Deskripi pada aspek realibility untuk kategori sangat puas sebesar $46,38 \%$, puas sebesar $47,83 \%$, kurang puas sebesar $4,34 \%$ dan tidak puas sebesar 1,44\%. Adapun untuk kategori sangat tidak puas tidak memiliki prosentase.

3) Aspek responsiviness

Pada aspek responsiviness, dengan 6 pertanyaan maka skor ideal adalah $6-$ 30. Adapun untuk nilai minimum pada sebesar 30, nilai mean $=23.623$, nilai median 24 dan nilai mode/modus sebesar 25 dengan standar deviasi sebesar 3.77. Untuk mengetahui prosentase tingkat kepuasan peserta didik pada aspek ini maka disusun nilai interval berdasarkan pilihan jawaban sebanyak 5. Berdasarkan hal tersebut dapat ditabulasi prosentase kepuasan pada aspek responsiviness sebagai berikut : aspek ini yaitu 13 dan nilai maxsimum

Tabel 4

Tingkat Kepuasan Peserta Didik pada Aspek Resposiviness

\begin{tabular}{cccc}
\hline Interval & Kategori & Hasil & Prosentase \\
\hline $26<30$ & Sangat Puas & 18 & 26,09 \\
\hline $21<25$ & Puas & 35 & 50,72 \\
\hline $16<20$ & Kurang Puas & 15 & 21,74 \\
\hline $11<15$ & Tidak Puas & 1 & 1,449 \\
\hline $6<10$ & Sanag Tidak Puas & 0 & 0 \\
\hline & Jumlah & 69 & 100 \\
\hline
\end{tabular}

Deskripi pada aspek responsiviness untuk kategori sangat puas sebesar $26,09 \%$, puas sebesar $50,72 \%$, kurang puas sebesar $21,74 \%$ dan tidak puas sebesar 1,44\%, sedangkan kategori sangat puas tidak ada.

4) Aspek assurance

Hasil pengukuran prosentase pada aspek assurance terhadap peserta didik, seperti yang tampak dalam tabel sebagai berikut :

Tabel 5

Tingkat Kepuasan Peserta Didik pada Aspek Assurance

\begin{tabular}{cccc}
\hline Interval & Kategori & Hasil & Prosentase \\
\hline $26<30$ & Sangat Puas & 29 & 42,03 \\
\hline $21<25$ & Puas & 36 & 52,17 \\
\hline
\end{tabular}




\begin{tabular}{cccc}
\hline $16<20$ & Kurang Puas & 4 & 5,797 \\
\hline $11<15$ & Tidak Puas & 0 & 0 \\
\hline $6<10$ & Sanag Tidak Puas & 0 & 0 \\
\hline & Jumlah & 69 & 100 \\
\hline
\end{tabular}

5) Aspek emphaty

Pada tabel berikut hasil pengukuran pada aspek emphaty :

Tabel 6

Tingkat Kepuasan Peserta Didik pada Aspek Emphaty

\begin{tabular}{cccc}
\hline Interval & Kategori & Hasil & Prosentase \\
\hline $26<30$ & Sangat Puas & 24 & 34,78 \\
\hline $21<25$ & Puas & 38 & 55,07 \\
\hline $16<20$ & Kurang Puas & 6 & 8,696 \\
\hline $11<15$ & Tidak Puas & 1 & 1,449 \\
\hline $6<10$ & Sanag Tidak Puas & 0 & 0 \\
\hline & Jumlah & 69 & 100 \\
\hline
\end{tabular}

Dari data diatas, dapat dilihat kontribusi tingkat kepuasan peserta didik banyak didorong oleh 2 faktor yang bisa dianggap dominan, yaitu pada aspek relibility dan assurance. Dua aspek tersebut pada tingkat kepuasan yaitu pada kategori sangat puas dan puas nilai prosentase yang dihasilkan sebesar $94 \%$.

\section{b. Orang Tua}

Adapun hasil olah data pada tingkat kepuasan pelanggan yaitu orang tua peserta didik dengan jumlah 90 orang sebagai responden dengan angket yang berjumlah 51 butir pernyataan dengan rentang skor $1-5$, sehingga diperoleh rentang skor ideal antara $51-255$. Setelah data ditabulasi, diskor, dan dianalisis dengan bantuan softwere hasil analisis data diperoleh nilai minimum $=139$; nilai maksimum $=242$; rata-rata $($ mean $)=$ 196,34; median $=195$; modus sebesar $=$ 195; standard deviasi $=20,201$. Deskripsi hasil penelitian tersebut dapat dikategorikan sebagai berikut :

Tabel 7

Deskripsi Hasil Penelitian Tingkat Kepuasan Orang Tua

\begin{tabular}{ccccc}
\hline No & Interval & Kategori & Hasil & Prosentase \\
\hline 1 & $215<255$ & Sangat Puas & 15 & 16,67 \\
\hline 2 & $176<214$ & Puas & 61 & 67,78 \\
\hline 3 & $134<175$ & Kurang Puas & 14 & 15,56 \\
\hline 4 & $92<133$ & Tidak Puas & 0 & 0,00 \\
\hline 5 & $51<91$ & Sangat Tidak Puas & 0 & 0,00 \\
\hline & Jumlah & 90 & 100
\end{tabular}


Berdasarkan tabel data diatas dapat dideskripsikan terakit hasil pengukuran tingkat kepuasan orang tua terhadap layanan pendidikan di SD Integral Lukman Al-Hakim bahwa pada kategori sangat puas ada 15 responden dengan prosentase sebesar $16,67 \%$, puas 61 responden dengan jumlah besaran prosentase sebesar $67,78 \%$ dan kurang puas sebesar 15,56\% dengan jumlah responden 14 orang tua. Adapun perincian deskripsi tingkat kepuasan pada masingmasing aspek sebagai berikut :

1) Aspek Tangibles.

Pada aspek tangibles, nilai mean sebesar 54,57, median 55, mode $/$ modus $=50$ dan nilai range 32 . Adapun nilai maximum sebesar 69 dan minimum sebesar 37 dengan standard deviasi 7.822. Untuk hasil tingkat kepuasan pada aspek tangibles dengan responden sebanyak 90 orang tua peserta didik dengan item pertanyaan 16 butir didapat hasil sebagai berikut :

\section{Tabel 8}

Tingkat Kepuasan Orang Tua pada Aspek Tangibles

\begin{tabular}{cccc}
\hline Interval & Kategori & Hasil & Prosentase \\
\hline $69<80$ & Sangat Puas & 1 & 1,11 \\
\hline $56<68$ & Puas & 42 & 46,67 \\
\hline $43<55$ & Kurang Puas & 39 & 43,33 \\
\hline $30<42$ & Tidak Puas & 8 & 8,89 \\
\hline $16<29$ & Sangat Tidak Puas & 0 & 0 \\
\hline & Jumlah & 90 & 100 \\
\hline
\end{tabular}

Didasarkan pada tabel diatas, untuk kategori sangat puas 1 responden dengan prosentase $1,11 \%$, kategori puas 42 responden dengan prosentase $46,67 \%$, kategori kurang puas $43,33 \%$ dengan 39 responden dan tidak puas dengan 8 responden dengan prosentase $8,89 \%$. Pada aspek ini kategori tingkat kepuasan hanya $47,78 \%$.

\section{2) Aspek Realibility}

Adapun hasil pengukuran pada aspek realibility dengan item pertanyaan 12 butir soal dengan 90 responden didapat hasil sebagai berikut :

Tabel 9

Tingkat Kepuasan Orang Tua pada Aspek Realibility

\begin{tabular}{cccc}
\hline Interval & Kategori & Hasil & Prosentase \\
\hline $52<60$ & Sangat Puas & 32 & 35,56 \\
\hline $42<51$ & Puas & 52 & 57,78 \\
\hline $32<41$ & Kurang Puas & 5 & 5,556 \\
\hline $22<31$ & Tidak Puas & 1 & 1,111 \\
\hline \multirow{2}{*}{$12<21$} & Sangat Tidak Puas & 0 & 0 \\
\hline & Jumlah & 90 & 100 \\
\hline
\end{tabular}


Didasarkan pada data diatas, untuk kategori sangat puas 32 responden dengan prosentase $35,6 \%$, kategori puas 52 responden dengan prosentase $57,8 \%$, kategori kurang puas $5,56 \%$ dengan 5 responden dan tidak puas dengan 1 responden dengan prosentase $1,11 \%$. Pada aspek ini kategori tingkat kepuasan mencapai 93,4 \%.

\section{Tabel 10}

\section{3) Aspek Resposiviness}

Hasil penelitian pada aspek responsiviness, untuk kategori sangat puas 25 responden dengan prosentase $27,8 \%$, kategori puas ada 58 responden dengan prosentase $64,4 \%$, kategori kurang puas $6,67 \%$ dengan 6 responden dan tidak puas dengan 1 responden dengan prosentase $1,11 \%$. Pada aspek ini kategori tingkat kepuasan mencapai 92,2 \%. Berikut tabel sebagai dasar deskripsi diatas :

Tingkat Kepuasan Orang Tua pada Aspek Responsivines

\begin{tabular}{|c|c|c|c|}
\hline Interval & Kategori & Hasil & Prosentase \\
\hline $34<40$ & Sangat Puas & 25 & 27,78 \\
\hline $27<33$ & Puas & 58 & 64,44 \\
\hline $20<26$ & Kurang Puas & 6 & 6,667 \\
\hline $14<19$ & Tidak Puas & 1 & 1,111 \\
\hline $8<13$ & Sangat Tidak Puas & 0 & 0 \\
\hline \multicolumn{2}{|c|}{ Jumlah } & 90 & 100 \\
\hline
\end{tabular}
pada aspek assurance dengan item butir

Tabel 11

Tingkat Kepuasan Orang Tua pada Aspek Assurance

\begin{tabular}{cccc}
\hline Interval & Kategori & Hasil & Prosentase \\
\hline $38<45$ & Sangat Puas & 27 & 30 \\
\hline $31<37$ & Puas & 57 & 63,33 \\
\hline $24<30$ & Kurang Puas & 6 & 6,667 \\
\hline $17<23$ & Tidak Puas & 0 & 0 \\
\hline $9<16$ & Sangat Tidak Puas & 0 & 0 \\
\hline & Jumlah & 90 & 100
\end{tabular}

5) Aspek Emphaty dalam kusioner penelitian dengan 6 butir terakhir

Pada aspek emphaty sebagai aspek ertanyaan, didapat hasil sebagai berikut :

Tabel 12

Tingkat Kepuasan Orang Tua pada Aspek Emphaty

\begin{tabular}{cccc}
\hline Interval & Kategori & Hasil & Prosentase \\
\hline $26<30$ & Sangat Puas & 24 & 26,67 \\
\hline $21<25$ & Puas & 57 & 63,33 \\
\hline $16<20$ & Kurang Puas & 8 & 8,889 \\
\hline
\end{tabular}

82 | Bahar Agus Setiawan : Tingkat Kepuasan Pelanggan Terhadap Layanan Pendidikan Di SD Integral Lukman Al-Hakim Jember, Hal 73-84 


\begin{tabular}{cccc}
\hline $11<15$ & Tidak Puas & 1 & 1,111 \\
\hline $6<10$ & Sangat Tidak Puas & 0 & 0
\end{tabular}

\begin{tabular}{l}
\hline Jumlah \\
\hline Tingkat kepuasan orangtua dari 5 \\
aspek yang diukur, 4 aspek tingkat \\
kepuasan < 90\% meliputi aspek \\
realibility, responsivines, assurance dan \\
emphaty. Sedangkan untuk aspek \\
tangibles tingkat kepuasan orang tua \\
hanya 48\%.
\end{tabular}

\section{Tingkat Kepuasan Pelanggan Pendidikan Di SD Integral Lukman Al- Hakim Jember.}

SD Integral Lukman Al-Hakim Jember meskipun tidak secara eksplisit mendudukkan pada konsep Full Day School, namun secara implisit dalam terminologi analisis sistem full day school, SD Integral Lukman Al-Hakim mengimplementasikan prinsip-prinsip konsep full day school mulai dari 5 hari sekolah, jam belajar mulai $7.00 \mathrm{sd} 14.00$, pengintegrasian kurikulum nasional dengan muatan lokal berbasis keislaman dan lainnya. Seperti yang dikemukakan oleh Baharudin (2009 : 227), full day school merupakan program yang memadukan sistem pengajaran Islam secara intensif yaitu dengan memberi tambahan waktu khusus untuk pendalaman keagamaan siswa. Menegaskan hal tersebut bahwa SD Integral Lukam Al-Hakim Jember masuk dalam bingkai full day school, bahwa karakteristik yang paling mendasar dalam model pembelajaran full day school yaitu proses Integrated curriculum dan integrated activity yang merupakan bentuk pembelajaran yang diharapkan dapat membentuk anak (siswa) yang berintelektual tinggi yang dapat memadukan aspek keterampilan dan pengetahuan dengan sikap yang baik dan Islami (Setyani dkk, 2014 : 231-244).

\section{Layanan pendidikan SD Integral} Lukman Al-Hakim berdasarkan data yang diperoleh menunjukkan bahwa tingkat kepuasan dalam perspektif peserta didik mencapai $99,9 \%$ dengan $52,17 \%$ pada posisi sangat puas dan $47,82 \%$ pada posisi puas. Sedangkan untuk tingkat kepuasan orang tua sebagai sebagai konsumen pendidikan (Mukminin, 2009 : 55), di SD Integral Lukman Al-Hakim mencapai $84,45 \%$, sedangkan sisanya $15,55 \%$ menyatakan kurang puas.

Gambaran tingkat kepuasan ini memang tidak lepas dari loyalitas orang tua dan prestasi akademik dan non akademik yang diraih oleh peserta didik SD Integral Lukman Al-Hakim Jember baik tingkat lokal, regional maupun nasional. Tingkat kepuasan ini mampu mendorong pada tingkat elektabilitas SD Integral Lukman Al-Hakim Jember terbukti dengan jumlah siswa pada setiap tahunnya mengalami kenaikan dengan seleksi yang ketat. Fakta ini tidak lepas dari beberapa manfaat kepuasan pelanggan yang diungkapkan oleh Irine (2009 : 61-62) salah satunya adalah kepuasan pelanggan akan berdampak pada kembalinya pelanggan. Hal ini tidak bisa dilepaskan dari konsep kepuasan itu sendiri. Menurut Juran (1993 : 3) tentang definisi singkat kualitas bahwa kualitas adalah kepuasan pelanggan. Dengan kata lain tingkat kepuasan sejalan dengan kualitas layanan dan mutu pendidikan itu sendiri.

\section{KESIMPULAN}

Berdasarkan pada paparan data dari hasil penelitian diatas, didasarkan pada rumusan masalah yaitu bagaimanakah tingkat kepuasan pelanggan di SD Integral Lukman Al-Hakim Jember dapat disimpulkan tingkat kepuasannya 
pelanggan pada kategori tinggi dengan prosentase sebesar $99,9 \%$ pada peserta didik dan $84,45 \%$ pada orang tua.

\section{DAFTAR PUSTAKA}

Alma, B. dan Hurriyati, R. (2008). Manajemen Corporate dan Strategi Pemasaran Jasa Pendidikan Fokus Pada Mutu dan Layanan Prima, Bandung : Alfabeta.

Arifin, Zainal . (2012). Pengembangan Managemen Mutu Kurikulum Pendidikan Islam. Yogyakarta : DIVA Press, cet. 1 .

Band, W. A. (1991). Creating Value for Customer: Designing and Implementation a Total Corporate Strategy, Canada : John Walley and Sons Inc.

Creswell, J. W. (2008). Educational Research : Planning, Conducting, and Evaluating Quantitative and Qualitative Reseacrh, New Jersey : Pearson Education.

Fadjar, Malik. (1998). Madrasah dan Tantangan Modernitas. Bandung : Mizan.

Insead Published, (2015). Blue Ocean Strategy Creating new market space where competition is irrelevant dalam https://centres.insead.edu/blueocean-strategy/documents/eibosi2015.pdf. (online) diakses 14 Maret 2017.

Irine. Kurniawan. (2009). "Atribut Kewirausahaan dan Perkembangan Industri Usaha Furniture Keluarga Di Jawa Timur". dalam http://digilib. petra.ac.id/viewer.php?page $=2 \&$ su bmit. $\mathrm{x}=$ $18 \&$ submit. $y=17 \&$ submit=next\&q ual=high\&submitval=next \&fname $=/$ jiunkpe/s1/eman/2009/jiunkpenss1-2009-31404189-11855- atribut-chapter2.pdf diakses pada tanggal 15 Oktober 2017 (online).

Juran. Joseph M. (1993). Quality Planning and Analysis. New York: McGraw-Hill. Third Edition.

Kotler, P. and Armstrong, G. (1996). Principles Of Marketing, Seventh Edition, International Editrion, Prentice Hall, Inc., Englewood Cliffs, New Jersey.

Moleong, Lexy J. (2007). Metodologi Penelitian Kualitatif. Bandung : PT. Remaja Rosdakarya Offset.

Mowen, J. C. (1995). Customer Behavior. Prentice Hall, Inc, Englewood Cliffs, New Jersey, International Edition.

Muhaimin, dkk. (2001). Paradigma Pendidikan Islam: Upaya Mengefektifkan Pendidikan Agama Islam di Sekolah. Jakarta: Remaja Rosdakarya, cet.1.

Octavian, Henry Samurung. (2005). "Manajemen Pemasaran Sekolah sebagi Salah Satu Kunci Keberhasilan Persaingan Sekolah" dalam Jurnal Pendidikan Penabur No.05/Th.IV/Desember 2005.

Rossidy, Imron. (2009). Pendidikan Berparadigma Inklusif. Malang : UIN Malang Press.

84 | Bahar Agus Setiawan : Tingkat Kepuasan Pelanggan Terhadap Layanan Pendidikan Di SD Integral Lukman Al-Hakim Jember, Hal 73-84 